\title{
Okulograficzna analiza stopnia dostosowania podręczników szkol- nych do nauki języka angielskiego do potrzeb uczniów z dysleksją rozwojową. Cz. I: opis problemu badawczego, metodologia i wyniki badań psychologicznych ${ }^{1}$
}

An eye tracking analysis of the level of adjusting the school textbooks of English to the needs of dyslectic students. Part I: explication of the research problem, methods and results of the psychological testing

\section{Katarzyna Maria BOGDANOWICZ}

Gimnazjum i Liceum Programów Indywidualnych w Gdańsku-Oliwie

E-mail:kb.dyslexia@gmail.com,

\section{Katarzyna WIEJAK}

Instytut Badań Edukacyjnych, Warszawa/ Educational Research Institute, Warsaw

E-mail:k.wiejak@ibe.edu.pl,

\section{Agnieszka ANDRYCHOWICZ-TROJANOWSKA}

Uniwersytet Warszawski/ University of Warsaw

E-mail: a.andrychowicz@uw.edu.pl,

\section{Sambor GRUCZA}

Uniwersytet Warszawski/ University of Warsaw

E-mail: sambor.grucza@uw.edu.pl,

\begin{abstract}
There is a need for research concerning visual features of student friendly foreign language textbooks. Most dyslexia experts agree that dyslexic students experience problems in both their mother tongue and in foreign languages they study. Since the prevalence of developmental dyslexia ranges from 10 to $15 \%$, this problem concerns a significant percentage of foreign language textbook users. As a result, dyslexic students may learn from textbooks which are not suitable for them. The primary goal of our project is to answer the question about the relationship between the level of performance in tasks used in dyslexia identification, English decoding and eye tracking with the use of English language textbooks. In the first (psychological) part of our research we have assessed our subjects' literacy skills
\end{abstract}

1 Tekst powstał w ramach realizacji drugiej części projektu „Kształtowanie kompetencji językowych u uczniów z dysleksją rozwojową" sfinansowanego przez MNiSW dotacją $\mathrm{Nr}$ 206428/E-343/S/2017-1 z dnia 12.12.2017 r. na pilne wykonanie badań naukowych lub prac rozwojowych szczególnie istotnych dla realizacji polityki naukowej, naukowotechnicznej lub innowacyjnej państwa. Drugą część projektu zrealizował zespół w składzie: prof. Sambor Grucza (kierownik), dr Agnieszka Andrychowicz-Trojanowska, dr Katarzyna Maria Bogdanowicz, dr Katarzyna Wiejak, dr hab. Monika Płużyczka. 
as an introduction to further research leading to conclusions about the ability to learn a foreign language based on foreign language textbooks.

Keywords: dyslexia, specific learning disorder, foreign language learning, textbook, eye tracking, adolescents

\section{Problem badawczy}

Mimo że początki świadomej refleksji na temat podręczników w Polsce sięgają działalności Komisji Edukacji Narodowej (!), to baza teoretyczna i empiryczna dotycząca tworzenia materiałów glottodydaktycznych jest, tak na gruncie polskim, jak i europejskim stosunkowo skromna. Nie będzie zatem przesadą stwierdzenie, że praktyka tworzenia podręczników do nauki języka obcego znacznie wyprzedziła refleksję naukową. W konsekwencji, na ogół nie uwzględniają one potrzeb uczniów ze specyficznymi zaburzeniami czytania i pisania.

Historia badań naukowych nad dysleksją rozwojową w Polsce sięga lat sześćdziesiątych dwudziestego wieku, podczas gdy w Europie została zapoczątkowana kilkadziesiąt lat wcześniej (G. Krasowicz-Kupis 2008). Badania nad nabywaniem języka obcego przez osoby z tym zaburzeniem mają znacząco krótszą historię. Jednak i na tym polu udało się sformułować pewne wnioski, z których najważniejszy brzmi następująco: im większe zdolności w posługiwaniu się językiem ojczystym (L1), tym łatwiejsze nabywanie i posługiwanie się językiem obcym (L2). Oznacza to, że osoby z dysleksją, które doświadczają trudności w L1, najprawdopodobniej będą miały również problemy w nauce L2 (R. Ganschow/ R.L. Sparks 2000, R.L. Sparks i in. 2012). Różnorodne trudności uczniów z dysleksją w uczeniu się języków obcych w Polsce stwierdzono w badaniach m.in. A. Jurek (2004), J. Nijakowskiej (2010), M. Łockiewicz i M. Jaskulskiej (2015, M. Jaskulska/ M. Łockiewicz 2017, M. Łockiewicz i in. 2018). Aktualny przegląd tych badań czytelnik znajdzie m.in. w artykule M. Łockiewicz i I. Pietras (2018). Tym bardziej zaskakuje fakt, że badania naukowe nie podejmują problemu dotyczącego tego, czy, a jeżeli tak, to w jakim stopniu dysleksja rozwojowa determinuje zdolność internalizacji (wytwarzania/ uczenia się) kompetencji w zakresie języka obcego w oparciu o podręczniki do nauki języka obcego - ani w obrębie szeroko pojętej glottodydaktyki, ani psychologii.

Szacuje się, że częstość występowania dysleksji rozwojowej na świecie wynosi od 10 do 15\% (wg. American Psychiatric Association 2013). W ciągu ostatnich kilkudziesięciu lat w Polsce znacznie wzrósł odsetek wydawanych opinii stwierdzających dysleksję rozwojową. Przyczyn wspomnianego wzrostu należy szukać w przemianach polityczno-społecznych, jakie zaszły w Polsce po 1989 roku, w efekcie których pojawiła się możliwość swobodnego przepływu ludzi i informacji oraz rewolucji technologicznej, która doprowadziła do upowszechnienia się Internetu. Znaczącą rolę w propagowaniu wiedzy o dysleksji rozwojowej odegrało także założone w 1990 roku przez M. Bogdanowicz Polskie Towarzystwo Dysleksji. Wymienione czynniki spowodowały wzrost świadomości społecznej, w wyniku której poprawił się dostęp do specjalistów i profesjonalnej diagnozy. Skuteczność diagno- 
zowania wzrosła jednak przede wszystkim dzięki naukowcom, którzy w swoich badaniach podejmowali temat specyficznych zaburzeń czytania i pisania. Zasadniczy postęp w procedurze diagnozy przyniosło zainteresowanie wczesnymi symptomami dysleksji i wprowadzenie przez M. Bogdanowicz terminu „ryzyko dysleksji”, które można rozpoznać jeszcze przed rozpoczęciem przez dziecko nauki czytania i pisania (M. Bogdanowicz 2011). Wspomniana zmiana doprowadziła do opracowania specjalistycznych narzędzi diagnostycznych do oceny dysleksji i jej ryzyka (G. Krasowicz-Kupis i in. 2014, K.M. Bogdanowicz i in. 2015, G. Krasowicz-Kupis/ K. Wiejak 2017).

Termin dysleksja oznacza trudności obejmujące poprawne i płynne rozpoznawanie słów (słabe dekodowanie), którym może towarzyszyć niska sprawność pisania (K.M. Bogdanowicz i in. 2015). Zdiagnozowanie dysleksji jest możliwe po wykluczeniu uszkodzeń neurologicznych, niepełnosprawności intelektualnej, znaczących defektów zmysłów czy zaniedbań społeczno-kulturowych (G. KrasowiczKupis 2008). W międzynarodowych klasyfikacjach chorób takich jak DSM V czy ICD-10 dysleksja jest zaliczana do grupy zaburzeń neurorozwojowych, ponieważ współczesne badania stwierdziły $\mathrm{w}$ tej grupie drobne zmiany struktury i funkcji ośrodkowego układu nerwowego, które mogły powstać w okresie pre-, peri- lub postnatalnym (M. Bogdanowicz 2017).

W świetle współczesnych danych, kluczowym i najlepiej udokumentowanym deficytem odpowiedzialnym za trudności w nauce czytania i pisania jest deficyt w zakresie rozwoju językowego. Dotyczy on głównie świadomości fonologicznej oraz przetwarzania fonologicznego, czyli manipulowania abstrakcyjnymi reprezentacjami dźwięków mowy (A. Gallagher i in. 2000, G. Krasowicz-Kupis 2008, G. Brookes i in. 2011). Badania wskazują, że sposób czytania uczniów z dysleksją wskazuje na niski poziom przetwarzania fonologicznego (G. Krasowicz-Kupis 2008). Mimo że deficyt fonologiczny jest najlepiej udokumentowany w literaturze przedmiotu, wiele badań pokazuje, że osoby z dysleksją cechują się także obniżonym rozwojem pozostałych aspektów języka, w tym słownika, morfologii i gramatyki. Deficyty w tym zakresie często ujawniają się zanim dziecko rozpocznie naukę czytania i pisania (G. Krasowicz-Kupis 2008, G. Krasowicz-Kupis/ K. Wiejak 2016, K. Wiejak i in. 2017b). Badania wskazują również na istotny związek pamięci roboczej z poziomem czytania, zależny od badanego aspektu umiejętności czytania (rozpoznawanie liter, nazywanie liter, dekodowanie słów lub pseudosłów), poziomu edukacyjnego oraz mierzonego aspektu pamięci roboczej (K. Wiejak i in. 2017a). Koncepcja deficytu fonologicznego jako teoria wskazująca na poznawcze patomechanizmy dysleksji jest uzupełniana przez nowe hipotezy wskazujące na inne, poza językowymi, deficyty poznawcze w dysleksji (N. Gawron i in. 2014).

Zarówno wyniki badań naukowych, jak i obserwacje praktyków dowodzą, że objawy dysleksji zazwyczaj nie znikają po zakończeniu przez ucznia edukacji szkolnej, ale pozostają problemem do końca życia (A. Reid i in. 2007, D. Pollak 2012, K.M. Bogdanowicz i in. 2014). Stwierdzono także, że zarówno profil poznawczy osób z dysleksją, jak i symptomy tego zaburzenia zmieniają się na przestrzeni życia: są inne u dzieci, a inne u dorosłych (G. Krasowicz-Kupis 2008, M. Bogdano- 
wicz 2009, M. Łockiewicz/ K.M. Bogdanowicz 2013).

W świetle powyższych uwag należy stwierdzić, że istnieje pilna potrzeba zdefiniowania tego, jak powinny wyglądać podręczniki do nauki języka obcego, które byłyby przyjazne dla uczniów z dysleksją rozwojową.

Podstawowym celem podjętych tu badań jest próba odpowiedzi na pytanie o relację pomiędzy umiejętnościami czytania i pisania uczniów z dysleksją rozwojową a zdolnością internalizacji (wytwarzania/ uczenia się) kompetencji w zakresie języka obcego w oparciu o podręczniki do nauczania języka obcego. Ze względu na to, że internalizacja kompetencji językowych/ komunikacyjnych jest zawsze procesem związanym z jakimś konkretnym językiem, przedmiotem zainteresowania projektu był język angielski. Badaniami objęto dwie grupy polskich uczniów z gimnazjum i liceum: 1. z dysleksją rozwojową (grupa kryterialna - D), 2. bez tego zaburzenia (grupa kontrolna - ND). Badania zaliczyć trzeba do badań podstawowych z interdyscyplinarnego obszaru z zakresu lingwistyki, psychologii i glottodydaktyki.

Okulograficzne badanie ruchów gałek ocznych pozwala na zebranie bardzo dużej ilości danych na temat przebiegu procesów poznawczych, tak percepcyjnych, pamięciowych, jak i wyobrażeniowych. Okulografia jest precyzyjną metodą badania uwagi wzrokowej, pozwalającą na prowadzenie analiz procesów poznawczych w czasie czytania. Jej zastosowanie pozwala lepiej zrozumieć proces czytania i przetwarzania informacji zawartych $\mathrm{w}$ tekście, $\mathrm{w}$ tym przypadku podręcznika do nauki języka angielskiego. Podstawową zaletą badan okulograficznych jest możliwość weryfikacji rozważań teoretycznych poprzez ich konfrontację z danymi empirycznymi (por. A. Duchowski 2007, K. Holmqvist i in. 2011, S. Grucza 2011, 2013a, 2013b, 2015, 2016, M. Płużyczka 2015, A. Andrychowicz-Trojanowska 2018). Zapis ruchu gałek ocznych pozwala na zebranie wiarygodnych danych liczbowych, które po odpowiednim opracowaniu i analizie pozwalają na wyciąganie trudnych do podważenia, ponieważ opartych na liczbach, wniosków. Oprogramowanie okulografu daje możliwość analizowania zebranych danych na wiele sposobów i w różnych, bardzo użytecznych kombinacjach. Wszystko to daje badaczowi możliwość dostosowania sposobu przeprowadzania badania, jak również dalszej analizy zebranych danych do charakteru eksperymentu.

Projekt zrealizowany został w dwóch częściach. Pierwszą część badań przeprowadzono w liceach w Katowicach, Sosnowcu i Dąbrowie Górniczej. Badaniu poddano 90 uczniów. Tę część badań przeprowadził zespół w składzie: prof. Sambor Grucza (kierownik), dr Agnieszka Andrychowicz-Trojanowska, dr hab. Monika Płużyczka. Drugą część projektu zrealizowano w Gdańsku z udziałem licealistów i gimnazjalistów. W skład zespołu badawczego wszedł: prof. Sambor Grucza (kierownik), dr Agnieszka Andrychowicz-Trojanowska, dr Katarzyna Maria Bogdanowicz, dr Katarzyna Wiejak i dr hab. Monika Płużyczka. Badania odbywające się w Gdańsku podzielono na dwa etapy. W pierwszym wykorzystano testy psychologiczne, których celem była ocena poziomu czytania (dekodowania wyrazów, dekodowania pseudowyrazów i czytania ze zrozumieniem), pisania oraz przetwarzania fonologicznego w języku polskim itd. Przeprowadzone badanie pozwalało także na stwierdzenie poziomu umiejętności dekodowania niepowiązanych wyrazów w języ- 
ku angielskim. Tę część badań przeprowadziły dr K.M. Bogdanowicz i dr K. Wiejak. Na drugą część badania składało się badanie okulograficzne przeprowadzone przez prof. S. Gruczę oraz dr A. Andrychowicz-Trojanowską.

Instytucjonalnie projekt przeprowadzony został w „Pracowni Badań Okulograficznych" (http://pbo.uw.edu.pl) ${ }^{2}$. Nadrzędnym zadaniem Pracowni jest prowadzenie badań naukowych w zakresie okulograficznej lingwistyki eksperymentalnej, w szczególności translatoryki eksperymentalnej i glottodydaktyki eksperymentalnej. W centrum zainteresowań badań okulograficznych stawiani są konkretni mówcysłuchacze, ich właściwości językowe, a także procesy językowe, jakie zachodzą w ich mózgach. Okulografia jest precyzyjną metodą badania uwagi wzrokowej, pozwalającą na prowadzenie analiz procesów poznawczych w czasie czytania. Jej zastosowanie pozwoli lepiej zrozumieć proces czytania i przetwarzania informacji zawartych w tekście do nauki języka angielskiego.

Pracownia dysponuje okulografem SMI RED 500 wraz z pełnym oprogramowaniem umożliwiającym przeprowadzanie badań tekstów, filmów wideo, aktywnych stron internetowych oraz gier (oprogramowanie BeGaze). Okulograf ten rejestruje dane z jedną z czterech możliwych częstotliwości próbkowania $(60 \mathrm{~Hz}, 120 \mathrm{~Hz}, 250$ $\mathrm{Hz}$ i $500 \mathrm{~Hz}$; na chwilę obecną jest to najszybszy okulograf mobilny na rynku) i cechuje go wysoki stopień kompatybilności optycznej (tolerancji na szkła kontaktowe i okulary). Jego dużą zaletą jest precyzja w mierzeniu ruchów sakadowych i minimalny czas latencji - odchylenie pomiaru jest mniejsze niż $0,4^{\circ}$, latencja jest mniejsza niż $10 \mathrm{~ms}$, natomiast obszar śledzenia wynosi $40^{\circ} \mathrm{w}$ poziomie $(+/-20)$ oraz $60^{\circ} \mathrm{w}$ pionie $(+20 /-40)$.

Poniżej przedstawione zostaną wyniki badania psychologicznego, a w kolejnym artykule niniejszego tomu zostanie przedstawione wprowadzenie do przeprowadzonych w ramach projektu badań okulograficznych. Natomiast same wyniki tych badań przedstawimy w kolejnych publikacjach.

\section{Procedura ${ }^{3}$}

Badania przeprowadzono w okresie od czerwca do listopada 2018 roku na terenie Gimnazjum i Liceum Programów Indywidualnych oraz V Liceum Ogólnokształcącego im. Stefana Żeromskiego w Gdańsku. Badania miały charakter indywidualnych spotkań z dyplomowanym psychologiem. Udział w badaniu był dobrowolny. Każdy $\mathrm{z}$ uczniów podpisał pisemną zgodę na udział w badaniu. W przypadku osób niepełnoletnich dodatkowo uzyskano zgodę ich rodziców, co jest zgodne ze „Standardami diagnozy psychologicznej w edukacji” (2018). Badanie trwało ok. 60 min.

\footnotetext{
${ }^{2} \mathrm{~W}$ sprawie innych projektów zob. http://pbo.uw.edu.pl/research/our-research.

${ }^{3}$ Autorzy pragną bardzo serdecznie podziękować panu Piotrowi Bogdanowiczowi, dyrektorowi Gimnazjum i Liceum Programów Indywidualnych, oraz pani Elżbiecie Piszczek, dyrektor V Liceum Ogólnokształcącego im. Stefana Żeromskiego w Gdańsku, za umożliwienie przeprowadzenia badania psychologicznego i okulograficznego w szkole. Szczególne dziękujemy panu Krzysztofowi Rześniowieckiemu, pedagogowi z V Liceum Ogólnokształcącego im. Stefana Żeromskiego w Gdańsku, za pomoc w organizacji badań.
} 


\section{Metody}

$\mathrm{W}$ badaniu zastosowano wybrane zadania $\mathrm{z}$ wystandaryzowanego testu „Bateria metod diagnozy przyczyn niepowodzeń szkolnych u osób powyżej 16 roku życia. Bateria 16 plus” (M. Bogdanowicz i in. 2016; dalej: „Bateria 16 plus”) oraz opracowaną przez Katarzynę Marię Bogdanowicz próbę dekodowania słów w języku angielskim.

\subsection{Bateria metod diagnozy przyczyn niepowodzeń szkolnych u osób powyżej 16 roku życia. Bateria 16 plus}

„Bateria 16 plus” jest, zdaniem jej autorów, przeznaczona do diagnozowania specyficznych zaburzeń czytania i pisania u osób dorosłych. Podstawą konstrukcyjną baterii jest „szeroka definicja dysleksji” (M. Bogdanowicz i in. 2016: 13), uwzględniająca zarówno dobrze opisane patomechanizmy specyficznego zaburzenia czytania i pisania, takie jak deficyt fonologiczny i deficyt tempa nazywania, jak również zaburzoną integrację percepcyjno-motoryczną. Jak piszą autorzy, „Bateria 16 Plus” uwzględnia diagnozę funkcji słuchowo-językowych, wzrokowo-przestrzennych i wzrokowo-ruchowych. W niniejszych badaniach zastosowano cztery podtesty, wchodzące w skład „skróconej wersji badania”. Jak czytamy w podręczniku testowym, o wyborze tych, a nie innych podtestów do wersji skróconej zadecydowała obecność różnic międzygrupowych pomiędzy osobami z i bez diagnozy dysleksji rozwojowej. Zastosowane w badaniu podtesty to:

1. Synteza fonemowa. Celem testu jest ocena umiejętności dokonywania syntezy fonemowej pseudosłów. Test służy ocenie sprawności fonologicznych. Wynik uzyskany w badaniu jest sumą punktów za każde poprawnie zsyntetyzowane słowo. Rzetelność testu wynosi 0,71 .

2. Dyktando. Celem testu jest ocena umiejętności pisania ze słuchu, poprawności zapisu, tempa pisania i sprawności pamięci słuchowej bezpośredniej. W analizie dla potrzeb badania uwzględniono jedynie aspekt ortograficzny i interpunkcyjny, czyli poprawność zapisu. Pominięto zaś ocenę poziomu graficznego pisma. Zadanie polega na zapisaniu tekstu dyktowanego przez badającego. Wynik stanowi łączna liczba błędów ortograficznych i specyficznych (np. nieprawidłowa segmentacja wyrazu lub zdania), interpunkcyjnych oraz pominięcia wyrazów. Autorzy nie podają rzetelności testu.

3. Łatysz. Test mierzy tempo i poprawność czytania (dekodowania) sztucznych słów. Badany czyta prezentowane słowa przez 60 sekund. Wynikiem jest liczba słów przeczytanych w ciągu 1 minuty. Autorzy nie podają rzetelności testu.

4. Czytanie głośne. Test służy ocenie tempa głośnego czytania tekstu wiązanego (tzn. stanowiącego treściową całość) oraz poziomu jego rozumienia. Tempo czytania oceniane jest przez liczbę słów przeczytanych w ciągu 1 minuty oraz czas czytania całego tekstu. Poziom rozumienia jest oceniany w oparciu o odpowiedzi na 6 pytań do przeczytanego tekstu. Rzetelność testu jest niezadowalająca i dla rozumienia wynosi 0,64 , dla pozostałych wskaźników autorzy nie podają rzetelności testu. 
Wybór zastosowanej w badaniu baterii testowej został podyktowany tym, że było to jedyne dostępne, wystandaryzowane narzędzie dla tej grupy wiekowej.

\subsection{Zadanie dekodowania słów w języku angielskim}

Jest to opracowana na potrzeby tego badania eksperymentalna próba dekodowania niepowiązanych wyrazów w języku angielskim. Zadaniem badanego było głośne odczytanie w ciągu 60 sekund wyrazów prezentowanych na planszy. Wyrazy zostały dobrane w następujący sposób: w losowo wybranych tekstach z popularnych podręczników do nauki języka angielskiego dla gimnazjalistów i licealistów przepisano co trzydzieste słowo. Pomijano słowa, które (a) liczyły mniej niż trzy litery, (b) powtarzały się, (c) były nazwą własną, (d) zostały zapisane cyfrą itp. Próba zawierała 79 wyrazów. Sposób konstrukcji tego zadania jest oparty na powszechnie stosowanej procedurze tworzenia testów dekodowania wyrazów.

W ocenie brano pod uwagę ogólną liczbę wyrazów przeczytanych w ciągu 60 sekund, liczbę wyrazów przeczytanych poprawnie oraz liczbę błędów (oznaczającą każdy błędnie przeczytany wyraz, o ile nie został on poprawiony przez badanego).

\section{Osoby badane}

Warunki uczestnictwa w badaniu były następujące: (a) wiek: 16-19 lat, (b) brak konieczności korzystania z okularów podczas czytania (w związku z ograniczeniami badania okulograficznego), (c) norma intelektualna, (d) brak choroby neurologicznej, (e) czytelne pismo, (f) polskojęzyczność (do badania nie dopuszczono uczniów, których pierwszym językiem nie był język polski oraz osób dwujęzycznych).

W badaniu psychologicznym uczestniczyło 60 uczniów obojga płci. Byli to w większości uczniowie Gimnazjum i Liceum Programów Indywidualnych oraz V Liceum Ogólnokształcącego im. Stefana Żeromskiego w Gdańsku, w wieku od 16 lat do 19 lat i 10 miesięcy. Czworo badanych to uczniowie 3 klasy gimnazjum, pozostali to uczniowie klas 1-3 liceum ogólnokształcącego.

Badanych podzielono na 2 grupy: kryterialną (z dysleksją - D) i kontrolną (bez dysleksji - ND). Pierwotne założenie podziału na grupy zakładało uwzględnienie 2 kryteriów doboru: opinii z poradni psychologiczno-pedagogicznej oraz potwierdzonego $\mathrm{w}$ aktualnym badaniu diagnostycznym $\mathrm{z}$ zastosowaniem skróconej wersji „Baterii 16 Plus”, niskiego poziomu czytania, pisania oraz przetwarzania fonologicznego. Zgodnie z zapisami z podręcznika do „Baterii 16 plus”, podstawą diagnozowania dysleksji jest niski na tle grupy wiekowej poziom przynajmniej kilku diagnozowanych sfer. Ze względu na to, że badani z opiniami po uwzględnieniu odniesienia do norm wiekowych uzyskiwali wyniki w zakresie wymienionych funkcji na poziomie przeciętnym, podjęto decyzję o oparciu podziału na grupę kryterialną i kontrolną tylko na podstawie opinii z poradni psychologiczno-pedagogicznej. Pozostałe zmienne są kontrolowane i uwzględnione w dalszych analizach. Grupę kryterialną (D) stanowili uczniowie posiadający opinię poradni psychologicznopedagogicznej o dysleksji lub dysortografii, z których niektórzy mieli jednocześnie dysgrafię. Grupę kontrolną (ND) tworzyli uczniowie nieposiadający takiej opinii. 
Charakterystykę badanych grup przedstawia Tabela 1.

\begin{tabular}{|l|c|c|}
\hline Płeć & $\begin{array}{c}\text { Grupa kryterialna } \\
\text { (D) }\end{array}$ & $\begin{array}{c}\text { Grupa kontrolna } \\
\text { (ND) }\end{array}$ \\
\hline Męska & 11 & 9 \\
\hline Źeńska & 15 & 16 \\
\hline Razem & 26 & 25 \\
\hline
\end{tabular}

Tabela 1. Charakterystyka osób badanych.

\section{Wyniki badania}

Statystyki opisowe (średnie i odchylenia standardowe) dla wyników zastosowanych testów przedstawia Tabela 2.

\begin{tabular}{|c|c|c|c|c|c|}
\hline \multirow[t]{2}{*}{ Nazwa testu } & \multicolumn{2}{|c|}{$\begin{array}{c}\text { Grupa kryterialna D } \\
(\mathrm{N}=26)\end{array}$} & \multicolumn{2}{|c|}{$\begin{array}{c}\text { Grupa kontrolna ND } \\
\qquad(\mathrm{N}=25)\end{array}$} & \multirow[t]{2}{*}{$\mathrm{U}$} \\
\hline & $\mathrm{M}$ & SD & $\mathrm{M}$ & SD & \\
\hline Synteza fonemowa & 2,27 & 1,48 & 2,28 & 1,24 & 319,50 \\
\hline Latysz & 43,08 & 13,14 & 55,48 & 10,33 & $142,00 * * *$ \\
\hline Dyktando & 10,46 & 7,51 & 5,48 & 4,03 & $197,00 * *$ \\
\hline $\begin{array}{l}\text { Czytanie głośne - liczba } \\
\text { wyrazów przeczytanych w } \\
\text { ciągu } 1 \text { minuty }\end{array}$ & 102,46 & 21,91 & 126,16 & 9,36 & $86,00 * * *$ \\
\hline Czytanie głośne - czas & 144,15 & 43,21 & 113,24 & 12,02 & $150,00 * * *$ \\
\hline $\begin{array}{l}\text { Czytanie głośne - rozumie- } \\
\text { nie }\end{array}$ & 3,15 & 1,71 & 3,48 & 1,73 & 292,00 \\
\hline $\begin{array}{l}\text { Dekodowanie - wyrazy } \\
\text { angielskie - liczba }\end{array}$ & 58,63 & 22,17 & 72,16 & 12,05 & $149,00 * *$ \\
\hline $\begin{array}{l}\text { Dekodowanie - wyrazy } \\
\text { angielskie - błędy }\end{array}$ & 7,88 & 5,89 & 6,58 & 4,75 & 205,00 \\
\hline
\end{tabular}

Tabela 2. Statystyki opisowe dla wyników poszczególnych testów w grupie kryterialnej i kontrolnej; $* * * p<0,01, * * p<0,05$.

Porównania wyników grupy kryterialnej i kontrolnej dokonano za pomocą nieparametrycznego testu istotności różnic Manna-Whitneya.

Jak pokazują dane zawarte $\mathrm{w}$ tabeli 2 , istotne różnice między uczniami ze zdiagnozowaną dysleksją lub dysortografią a uczniami bez takiej diagnozy stwierdzono w zakresie dekodowania pseudosłów, czytania głośnego zarówno w zakresie liczby słów przeczytanych w ciągu 1 minuty jak i czasu czytania całego tekstu oraz w zakresie umiejętności pisania, rozumianej jako poprawność ortograficzna i interpunkcyjna. Grupy różniły się też istotnie poziomem dekodowania wyrazów w języku angielskim, przy czym różnica ta dotyczyła tempa czytania, czyli liczby wyrazów przeczytanych w ciągu 60 sekund. Jednocześnie nie stwierdzono różnic w zakresie poprawności dekodowania, mierzonej za pomocą liczby popełnionych błędów.

Zbadane grupy nie różniły się w zakresie umiejętności syntezy fonemowej pseudosłów i rozumienia tekstu czytanego głośno. Brak tych różnic może wynikać m.in. 
ze zbyt niskiej rzetelności zastosowanego w pomiarze narzędzia diagnostycznego. Ponad połowa badanych z obu grup uzyskała wyniki niskie w zakresie syntezy fonemowej pseudosłów. Ze względu na długość zastosowanych wyrazów test ten najprawdopodobniej jest w większym stopniu zależny od pojemności pamięci roboczej niż poziomu przetwarzania fonologicznego.

W analizie uwzględniono również poziom mierzonych funkcji na tle norm dla grupy wiekowej i typu placówki edukacyjnej. Wyniki przedstawia tabela 3.

\begin{tabular}{|l|c|c|c|c|c|c|}
\hline \multirow{2}{*}{ Nazwa testu } & \multicolumn{2}{|c|}{ Poziom niski } & \multicolumn{2}{c|}{ Poziom przeciętny } & \multicolumn{2}{c|}{ Poziom wysoki } \\
\cline { 2 - 7 } & $\mathrm{D}$ & $\mathrm{ND}$ & $\mathrm{D}$ & $\mathrm{ND}$ & $\mathrm{D}$ & ND \\
\hline Synteza fonemowa & 15 & 14 & 10 & 10 & 1 & 1 \\
\hline Latysz & 8 & 1 & 15 & 18 & 3 & 6 \\
\hline Dyktando & 18 & 10 & 5 & 9 & 3 & 6 \\
\hline $\begin{array}{l}\text { Czytanie głośne - } \\
\text { liczba wyrazów prze- } \\
\text { czytanych w ciągu 1 } \\
\text { minuty }\end{array}$ & 5 & 0 & 18 & 9 & 3 & 16 \\
\hline $\begin{array}{l}\text { Czytanie głośne - } \\
\text { rozumienie }\end{array}$ & 5 & 4 & 15 & 12 & 6 & 9 \\
\hline
\end{tabular}

Tabela 3. Liczba badanych o określonym poziomie diagnozowanych funkcji w oparciu o normy wiekowe dla uczniów gimnazjum i liceum.

Analiza wyników odniesionych do norm wiekowych pozwala scharakteryzować obie grupy z uwzględnieniem nie tylko różnic między ich średnimi wynikami, ale również poziomu rozwoju mierzonych funkcji.

(a) Poziom czytania pojedynczych pseudowyrazów rozumiany jako tempo i poprawność czytania u badanych z dysleksją i bez jest na ogół przeciętny (mieści się w normie dla wieku). Niski poziom tej umiejętności stwierdzono u 9 uczniów, z czego 8 to uczniowie z dysleksją.

(b) Poziom głośnego czytania tekstu w języku polskim (tempo i poprawność) $\mathrm{u}$ badanych z dysleksją jest w większości przypadków przeciętny, zaś u tych bez - wysoki.

(c) Poziom rozumienia czytanego tekstu w obu grupach był zbliżony.

(d) Przeciętny poziom w zakresie czytania pseudosłów i tekstu prawdopodobnie wiąże się z kompensacją i wieloletnim treningiem u badanych nastolatków. Wyniki badań dowodzą, że objawy dysleksji zmieniają się z wiekiem. Ze względu na to, że wyniki mieszczą się w normie, na ich podstawie nie można było dokonać podziału na grupy.

(e) Stwierdzono niski poziom poprawności ortograficznej i interpunkcyjnej w pisaniu tekstu ze słuchu w obu grupach. Najczęstsze rodzaje błędów jakie się pojawiały to błędy ortograficzne, błędy segmentacji, błędy o charakterze fonetycznym, błędy w segmentacji tekstu na zdania, błędy interpunkcyjne, nieprawidłowe użycie małej/wielkiej litery. Nie oceniano poziomu graficznego pisma. 


\section{Wnioski}

Przeprowadzone badania psychologiczne miały charakter pilotażowy. Ze względu na brak jednolitych procedur diagnozowania dysleksji, w doborze grupy kryterialnej planowano posłużyć się nie tylko opinią o specyficznych trudnościach szkolnych, wydaną przez poradnię psychologiczno-pedagogiczną, ale także wynikami psychologicznego badania diagnostycznego. Zakładano, że dzięki badaniu możliwe będzie wyłonienie uczniów spełniających kryteria diagnostyczne zawarte w klasyfikacji ICD-10, tj. uzyskujących wyniki w teście czytania na poziomie co najmniej o 2 odchylenia standardowe niższym od przewidywanego dla wieku. Jednak w związku $\mathrm{z}$ faktem, że analiza wyników ujawniła, że uwzględnieni w badaniu uczniowie posiadający opinie z poradni psychologiczno-pedagogicznych na ogół charakteryzowali się przeciętnym poziomem czytania niepowiązanych pseudowyrazów oraz tekstu ciągłego, zdecydowano o oparciu podziału na grupy wyłącznie na podstawie opinii z poradni. Opinie dotyczące badanych uczniów wskazywały na zaburzenia o charakterze dysleksji, dysortografii, którym to zaburzeniom czasem towarzyszyła dysgrafia. Przy takim podziale, mimo że poziom umiejętności czytania był w obu grupach na ogół przeciętny w porównaniu z normami, był on istotnie niższy w grupie kryterialnej niż w grupie kontrolnej. W kolejnych, zaplanowanych na szerszą skalę, badaniach warto by:

- zbadać większą liczbę badanych;

- uwzględnić pomiar objawów i funkcji poznawczych odwołujących się do patomechanizmu dysleksji (m.in. funkcje fonologiczne, werbalną pamięć krótkotrwałą, mierzoną za pomocą próby powtarzania cyfr) z zastosowaniem wystandaryzowanych, rzetelnych i trafnych metod;

- rozszerzyć zakres pomiaru funkcji fonologicznych, uwzględniając pamięć fonologiczną oraz świadomość fonologiczną (mierzoną za pomocą zadań polegających na usuwaniu głosek/sylab/ subsylab w wyrazach, tworzeniu spuneryzmów), co pozwoliłoby na bardziej szczegółową charakterystykę grup;

- na potrzeby analiz wyników z badań okulograficznych można by w przyszłości utworzyć podgrupy badanych spełniających jednocześnie oba kryteria: posiadających opinię oraz uzyskujących niskie wyniki w określonych testach (czytanie, dyktando itp.).

\section{Bibliografia}

American Psychiatric Association (2013), Diagnostic and statistical manual of mental disorders (5th ed.). Washington.

Andrychowicz-Trojanowska, A. (2018), Podręczniki glottodydaktyczne. Strukturafunkcja-potencjat w świetle badań okulograficznych. Warszawa.

Bogdanowicz, M. (2009), Dysleksja u osób dorostych, (w:) I. Sosin/ M. Matraszek (red.), Zeszyt terapeuty. Edukacja - profilaktyka - terapia. Warszawa, 52-61.

Bogdanowicz, M. (2011), Ryzyko dysleksji dysortografii i dysgrafii. Skala Ryzyka Dysleksji wraz z normami dla klas I i II. Gdańsk. 
Bogdanowicz, M. (2017), Zaburzenia komunikacji pisemnej-autorska propozycja modelu patomechanizmu dysleksji, (w:) A. Domagała/ U. Mirecka, (red.), Zaburzenia komunikacji pisemnej. Gdańsk, 44-86.

Bogdanowicz, M./ U. Sajewicz-Radtke/ B. Radtke/ D. Kalka/ E. Karpińska/ K. Bogdanowicz/ M. Łockiewicz (2016), Bateria diagnozy przyczyn niepowodzeń szkolnych u osób powyżej 16 roku życia. Bateria 16 plus. Gdańsk.

Bogdanowicz, K.M./ M. Łockiewicz/ M. Bogdanowicz/ M. Pąchalska (2014), Characteristics of Cognitive Deficits and Writing Skills of Polish Adults with Developmental Dyslexia, (w:) „International Journal of Psychophysiology” 93, 7883, doi: 10.1016/j.ijpsycho.2013.03.005.

Bogdanowicz, K.M./ K. Wiejak/ G. Krasowicz-Kupis/ N. Gawron (2015), Ocena przydatności Adult Reading History Questionnaire do diagnozy rodzinnego ryzyka dysleksji w Polsce, (w:) „Edukacja” 1(132), 117-138.

Brookes, G./ V. Ng/ B.H. Lim/ W.P. Tan/ N. Lukito (2011), The computer-based Lucid Rapid Dyslexia Screening for identification of children at risk of dyslexia: a Singapore study, (w:) „Educational \& Child Psychology” 28(2), 33-51.

Duchowski, A. (2007), Eye Tracking Methodology. Clemson.

Gallagher, A./ U. Frith/ M. Snowling (2000), Precursors of literacy delay among children at genetic risk of dyslexia, (w:) ,Journal of Child Psychology and Psychiatry", 41(2), 203-213.

Ganschow, L./ R.L. Sparks, (2000), Reflections on foreign language study for students with language learning problems: research, issues and challenges, (w:) „Dyslexia” 6, 87-100.

Gawron, N./ G. Krasowicz-Kupis/ K. Wiejak/ K. M. Bogdanowicz/ K. Jednoróg (2014), Niejęzykowe deficyty poznawcze u dzieci z dysleksja rozwojowa i jej ryzykiem - przegląd badań, (w:) „Psychologia Rozwojowa” 19(4), 15-30.

Grucza, S. (2011), Lingwistyka antropocentryczna a badania okulograficzne, (w:) „Lingwistyka Stosowana/ Applied Linguistics/ Angewandte Linguistik” 4, 149-162.

Grucza, S. (2013a), Die Augen reden mächtiger als die Lippen: Eye-Tracking„Einblicke“ in die Sprache, (w:) ,Zeitschrift des Verbandes Polnischer Germanisten/ Czasopismo Stowarzyszenia Germanistów Polskich” 2/2013, 189-202.

Grucza, S. (2013b), Probleme? Nichts weiter als dornige Chancen: Zu Parametern und Maßeinheiten der Eye-Tracking-Translatorik, (w:) ,Studia Translatorica” 4, $11-22$.

Grucza, S. (2015), Eye-Tracking-Translatorik - Ein Erfahrungsbericht, (w:) „Mehrsprachigkeit und Multikulturalität in Forschung und Lehre (Studia Translatorica 6)". Wrocław/ Dreseden, 47-61.

Grucza, S. (2016), W sprawie translatoryki okulograficznej, (w:) „Lingwistyka Stosowana/ Applied Linguistics/ Angewandte Linguistik” 20(5), 51-64.

Holmqvist, K./ M. Nyström/ R. Andersson/ R. Dewhurst/ H. Jarodzka/ J. van de Weijer (2011), Eye Tracking. A comprehensive guide to methods and measures. New York.

Jaskulska, M./ M. Łockiewicz, (2017), Polish as L1, English as L2: the linguistic transfer impact on Second Language Acquisition stemming from the interlingual differences: implications for young learners education, (w:) ,Issues in Early Education" 2, 68-76. 
Jurek A. (2004), Trudności w nauce języków obcych uczniów z dysleksją rozwojowa, (w:) M. Bogdanowicz/ M. Smoleń (red.), Dysleksja w kontekście nauczania języków obcych. Gdańsk, 98-116.

Krasowicz-Kupis, G. (2008), Psychologia dysleksji. Warszawa.

Krasowicz-Kupis, G./ K.M. Bogdanowicz/ K. Wiejak (2014), Familial risk of dyslexia in Polish first grade pupils based on the ARHQ-PL Questionnaire, (w:) „Health Psychology Report” 4(2), 237-246.

Krasowicz-Kupis, G./ K. Wiejak (2017). Diagnoza ryzyka specyficznego zaburzenia uczenia się w obszarze czytania i pisania z wykorzystaniem baterii diagnostycznych IBE, (w:) A. Domagała/ U. Mirecka, (red.), Zaburzenia komunikacji pisemnej. Gdańsk, 617-647.

Łockiewicz, M./ K.M. Bogdanowicz (2013), Dysleksja u osób dorostych. Kraków.

Łockiewicz M./ M. Jaskulska (2015), Mental lexicon, working memory and L2 (English) vocabulary in Polish students with and without dyslexia. (w:) „Center for Educational Policy Studies Journal" 5(1), 71-89.

Łockiewicz, M./ I. Pietras (2018), Polska szkoła w multijęzykowej Europie. Analiza przebiegu edukacji językowej w odniesieniu do nauczania języków obcych, (w:) „Prace Językoznawcze” 20(1), 101-118.

Łockiewicz, M./ Z. Sarzała-Przybylska/ M. Lipowska (2018), Early Predictors of Learning a Foreign Language in Pre-school-Polish as a First Language, English as a Foreign Language, (w:) „Frontiers in Psychology” 9:1813, doi: 10.3389/fpsyg.2018.01813.

Nijakowska, J. (2010), Dyslexia in the Foreign Language Classroom. Bristol.

Płużyczka, M. (2015), Ttumaczenie a vista. Rozważania teoretyczne i badania eyetrackingowe. Warszawa.

Pollak, D. (2012), Studenci z dysleksja w Wielkiej Brytanii, (w:) M. Bogdanowicz (red.), Dysleksja w wieku dorosłym. Gdańsk, 167-197.

Reid, A./ M. Szczerbinski/ E. Iskierka-Kasperek/ P. Hansen, (2007), Cognitive Profiles of Adult Developmental Dyslexics: Theoretical Implications. Dyslexi, (w:) „An International Journal of Research and Practice” 13(1), 1-24.

Sparks, R.L./ J. Patton/ L. Ganschow (2012), Profiles of more and less successful L2 learners: a cluster analysis study, (w:) „Learning and Individual Differences” 22, 463-472. doi: 10.1016/j.lindif.2012.03.009.

Standardy diagnozy psychologicznei w edukacii (2018). (URL http://brpd.gov.pl/sites/default/files/standardy_diagnozy_psychologicznej_w_ed ukacji.pdf). [Dostęp 22.12.2018].

Wiejak, K./ R. Kaczan/ G. Krasowicz-Kupis/ P. Rycielski (2017a), Working memory and reading ability in chidren - a psycholoinguistic perspective, (w:) S. Jabłoński/ L. Liptáková (red.), Contribution to a special issue Executive functions and children's literacy development. "L1 - Educational Studies in Language and Literature" 17, 1-22 (URL https://doi.org/10.17239/L1ESLL2017.17.04.01). [Dostęp 22.12.2018].

Wiejak, K./ G. Krasowicz-Kupis/ E. Awramiuk (2017b), Językowe uwarunkowania wczesnych umiejętności czytania i pisania na podstawie oceny nauczyciela $z$ wykorzystaniem Skali Prognoz Edukacyjnych IBE, (w:) „Psychologia Wychowawcza" 11, 41-63. 